\title{
Towards Making a Green City: A Case Study of Ilam Municipality
}

- Pratik Poudel and Shao Ying Hong

This article reports a brief household survey done in every ward of Ilam municipality about the statuses of various prerequisites of a green city. The surveyer found out that the general household has only little knowledge about the concept of a green city. Similarly, chemical fertilizer was least used, which is a good sign. Many households still have traditional cooking stove which emits more smokes. Almost all households surveyed had a well-equipped sanitational facility. Many households complained that they were not receiving adequate drinking water. Even in the irrigation part, there were not enough irrigation sources.

\section{Introduction}

Human civilization has gone through various stages. The industrial revolution, which was the process of change from an agrarian, manual economy to the one dominated by mechanization, occured during the eighteenth century starting from England, was a milestone in the industrialization of the world $_{(1)}$. During those times, the physical development of the city was the major concern. The cost incurred by the nature was completely ignored. Similarly, there were lots of destructions made in the world in the name of development. And, eventually, it became fruitful to the people at that time and was replicated in various parts of the world. In this rapid progress, especially in the United States and the European region, the source of energy was needed. And coal and petroleum sources became the winner.

Now, in this modern world, it has been felt that the cost of the environment is completely ignored. Fossil Fuel plants contributed more than one third of the overall worldwide emissions. For the US alone, coal fired and natural gas power plants contributed more than $40 \%$ of the economy's total 6 giga 
tons of $\mathrm{CO} 2$ emissions. On a global scale, coal fired power plants alone contributed nearly 8 out of 28 giga tonnes of $\mathrm{CO} 2$ emissions in 2008 (2). As a result, the concept of "green economy" or environment friendly economy has been gaining momentum. In this growing world of industrialization, cities are becoming centre of attraction. Therefore, in the mission to make the world greener, the quest for making cities greener is gaining attention.

More than half of the world's population reside in urban areas and the figure will rise to more than two thirds by 2050 , according to United Nations forecast (3). Especially, in Asia, the rate of urbanization is increasing. China's urban population in 2010 was 636 million (4) China's urban population is expected to grow by 250 million; which is the whole population of Brazil; by 2025. (5). Increased urbanization in China will pose a variety of challenges including air and water pollution, solid waste management, and the loss of high-quality arable land (6). Even another booming economy, India, is following China in terms of urbanization. Some projections show that India's urban population will increase to 590 million by 2030 (7). Besides, there are various booming economies in Asia which have contributed to the problem of environment degradation through haphazard urbanization. If drastic changes are not made, Asia may contribute as much as $45 \%$ of global energy related Green House Gas (GHG) emissions by 2030 (8).. Therefore, the significance of greener economy can only be possible when the cities are made "green" since majority of the populations are living in the urban areas. The residents of cities are the major contributors to the global pollution and the largest emitter of the green house gases (GHGs). Urban areas are now home to $50 \%$ of the world's population but they are responsible for $60-80 \%$ of energy consumption and $75 \%$ of carbon emissions (9).

Even in smaller economies like Nepal, urbanization is rapid. The population growth rate of Kathmandu, the capital of Nepal, is $4.71 \%$ which is one of the highest in the world (10) In developing countries like Nepal, this problem is even worse. In 
the rural areas of developing countries, there are very less economic opportunities. So, people migrate to the urban areas in search of job and other economic opportunities. Due to these scenarios, there exists haphazard urban settlement. This is because of the lack of proper planning and measures taken to tackle this precarious problems. Besides, there are various complications in the governance system of developing countries. Due to inappropriate planning, weak institutions, lack of resources and poor implementation of policies, most big cities in the developing world have become even less sustainable, environmentally, economically and socially, than they were in the past ${ }_{(11)}$. There are various challenges that are being laid down because of environmental crisis such as acid rain, depletion of ozone layer, global warming, climate changes etc. But developed countries are in a better position to cope with these challenges because they are better equipped with money, skills and technologies (12). Therefore the concept of making cities greener should be significant in the developing countries as well, although they may not be the highest contributor to the global greenhouse gas emission.

In today's cities, there are lots of factors which generate green house gases (GHGs), as a result of which, the carbon emission is increasing. The International Panel on Climate Change (IPCC) has given various sources of GHG emissions. Among the sources, industry, transport, and production of electricity and heat is responsible for $20 \%, 13 \%$ and $20 \%$ respectively. Similarly waste and domestic and commercial heating are responsible $3 \%$ and $5 \%$ respectively (13). These various factors should be considered while constructing a green city, which should help in reducing the Green House Gas as least as possible. A green city is a geographical location which is environment friendly. UNEP in one of its report gives some pre requisites or indicators measuring "greenness" of cities namely; levels of pollution and carbon emission, energy and water consumption, water quality, energy mix, waste volumes and recycling rates, green-space ratios, primary forests, and agricultural land loss (meadows and brugmann, 99) (14). The greening of cities requires some or preferably all of the 
following requirements: controlling diseases and their health burden, reducing chemical as well as physical hazards, developing high quality urban environment for all, minimizing transfers of environmental costs to areas outside the city and ensuring progress towards sustainable consumption (satterwaite, 1997) In simple words, a green city is a city which is not harmful environmentally and at the same time leads to the mutual growth of the society as well as its residents.In the procedure of going towards a greener economy, the construction of a green city can help in making a secure future. Securing the natural resources not at the cost of human development should be the prime objective. Due to the massive unsustainable use of natural resources, soil erosion is a common phenomenan, especially in the hilly areas of Nepal. Therefore some of the solutions for this unsustainable use of natural resources are: curbing population growth, greater user management of resources (especially forests) and improving administrative capacity to manage public resources (15) So, envisioning this scenario, Ilam Municipality of Nepal, which is also a hilly area, has recently been announced as a "Green city". It is the first "green city" announced by the government of Nepal .

\section{Ilam Municipality}

Ilam Municipality is a beautiful hilly municipality located in the eastern part of Nepal. It is the eastern most municipality of Nepal adjoining Darjeeling of India on the other side. The main beauty of the region lies in the greenery. Ilam is naturally decorated with green hills and forest areas. Tea cultivation has given more beauty to the greenness. Giving due respect to this fact, Ilam Municipality was announced as green city.

The total area of the municipality is 27 sq.km., which is about $0.02 \%$ of total area of Nepal $(16)$. The total population of Ilam Municipality as of 2008 is 34618 and the annual population growth rate is $3.86 \%$. There are two hospitals. One is the district hospital located in ward number 2, the other is a community hospital located in ward number 8 (17) . However, 
the researcher found out that most of the people prefer to go to hospitals in nearby districts (Jhapa) or India, thinking they get a better treatment there.

The source of energy in is hydropower in this municipality. The municipality produces around 6.2 MW of hydropower (18). For cooking purpose, they either use LPG or firewood. The current water supply covers only six out of nine wards in the municipality. As far as the waste management is concerned, the municipality vehicle regularly comes to collect municipal solid waste from ward number 1 and 2, whereas the municipality vehicle partially serves the other wards in the municipality. The estimated waste generation per day from household is 6.00 tons/day. The major part of the municipal solid waste $(52 \%$ consist of organic a waste, the other remaining parts being paper, plastic, glasses, construction waste etc. (19). All of the households have built their own safety tank for human waste management.

Ilam is a most famous place for producing cash crops. Ilam is also a famous tourist destination for internal tourists. Slowly but steadily, it has started attracting tourist from foreign countries as well. In terms of agriculture, Ilam is famous for producing five major cash crops which are potato, cardamom, ginger, milk and broom grass. The annual total amount of chemical fertilizer used for agriculture is $28.76 \mathrm{Mt}$., whereas the total amount of chemical pesticides used is $150 \operatorname{Ltrs}_{(20)}$.

Ilam Municipality was announced as green city in 2010. The major motive behind the initiative is to ensure that urban life could be improved through an eco-friendly urban planning and development addressing social, environmental, economic, and health aspects $(21)$.

\section{Materials and Methods}

A brief household survey was done in all the wards of the municipality. A questionnaire was constructed which focused on six basic resources such as the interviewee's cooking source of energy, sanitation facility, solid waste management, drinking 
water source, use of chemical fertilizer and irrigational facilities. Altogether 126 households were surveyed. The numbers of households surveyed in different wards are as follows:

\begin{tabular}{|c|c|}
\hline Wards & No. of households surveyed \\
\hline 1 & 10 \\
\hline 2 & 18 \\
\hline 3 & 15 \\
\hline 4 & 15 \\
\hline 5 & 15 \\
\hline 6 & 15 \\
\hline 7 & 10 \\
\hline 8 & 13 \\
\hline 9 & 15 \\
\hline Total & 126 \\
\hline
\end{tabular}

Ward number 1 is the main bazaar ( central market) area which is also Ilam's business hub. Therefore, only samples of 10 households were surveyed. Ward number 2 is relatively larger in size. And besides, in ward number 2, which is around ward number 1, there lies Ilam's only government campus, Mahendra Ratna Multiple Campus. A lot of students who have come from various parts around Ilam District live around ward number 2. So, a relatively larger number of households was surveyed in ward number 2. Although an initial objective of surveying 15 households in every region was done, the benchmark of surveying at least 15 households was not met because of time constraints and the households were not present during the time of interview. SPSS version 20 was used in entering the questionnaire into the computer system.

\section{Limitations}

This research presents few flaws and limitations. Because the researcher did not have prior knowledge of the geographical locations, none of the sampling methods were followed. But the researcher has tried best to make it as comprehensive and representative as possible. Similarly other aspects of green city 
other than the household aspect are excluded. The main focus is done on the household's perspective and surrounding aspect. As already stated before, the focus was mainly on six basic resources such as the interviewee's cooking source of energy, sanitation facility, solid waste management, drinking water source, use of chemical fertilizer and irrigational facilities. In other aspects such as forest resources, the status of transportation etc., secondary sources were collected. Six resources were the basis of focus because although there are a lot of resources that need to be studied for making a green city but until and unless these six basic resources are not improved, the vision of a green city may not be possible. UNEP have also stated in one of its reports that "numerous instruments for enabling green cities are available and tested but need to be applied in a tailored, context-specific way (22)

\section{Results and Discussion}

Based on the household survey, the following results were achieved.

\section{Cooking source of energy}

More than $20 \%$ of the households surveyed are still dependent on firewood for cooking purpose. Other $39.68 \%$ are using either firewood or LPG as a cooking source. One third of the households surveyed (mostly in ward number 1 and 2) solely use LPG for cooking purpose. The use of firewood should be reduced to a substantial level for a greener city.

\section{Sanitation facility}

In this aspect, Ilam Municipality has gained significant achievement. $100 \%$ of the household surveyed had a sanitation facility at their home. Almost all household has a concrete toilet in their house. 


\section{Drinking water source}

More than two-third of the households had a municipal water connection. Although all of the households surveyed had a drinking water tap, many of them were unsatisfied by the timings of the supply, which is unevenly distributed. Even the people who were living in the bazaar area are not satisfied.

\section{Solid waste management}

Under this aspect, four questions were put forward to the interviewee. They are: do you segregate waste or not? What is the proportion of organic and inorganic waste? What do you do with the organic waste? And what do you do with the inorganic waste?

The finding shows that almost all of the household segregate waste. Only in the urban wards (ward number 1 and 2), they don not segregate waste. This is because the municipality comes to pick up waste everyday in these two wards. In the proportion of waste aspect, $77.8 \%$ of the households said the proportion of organic waste is more, while $13.5 \%$ said the portion of inorganic waste is more dominant. In the same way, more than two third of the participants said they either feed the organic waste to animals (household cows or pig) or compost it for manure. Only a small proportion said they give it to the municipality and only a single household was found doing vermin composting. Majority of the households living in the rural wards said they burn the inorganic waste like plastic.

\section{Use of chemical fertilizers}

In this aspect as well, Ilam Municipality has gained significant achievement. Many of the households said they used to use chemical fertilizers before, but now they have completely stopped using. 


\section{Irrigation facilities}

Ilam Municipality has a lot of improvements to make in irrigation. About one third (36\%) of the households who have agricultural land don't have irrigation facilities. Even among the households that have irrigation facility, only $56 \%$ have it for more than six months. The remaining 44\% don't have it for the remaining six months.

\section{Knowledge of green city}

Many of the households did not have knowledge of what a green city is or should be. Only $11 \%$ of the household said they have substantial knowledge of what a green city is. Some $44 \%$ are completely unaware of what a green city is. Some $43 \%$ said they just have heard the name.

\section{Green cities in other parts of the world}

\section{Gangneung clw-Carbon Green City (23):}

Gangneung is a city which is located in the eastern part of Republic of Korea. The Green city is located in Gyaenpo area of Gangneung. It was declared as a low carbon green city in 2009.

The Gangneung green city construction project is expected to reduce the green house gas emission by more than $80 \%$ through the construction of green lakes and improving the green transportation system. In 2009, the green house gas emission of the city was 240000 ton $\mathrm{CO}_{2}$. In the transportation domain, its aim is to develop a model to save energy and respond to climate change by promoting the use of bicycles and distributing green homes. It is expected to initiate various project activities in the following sectors:

\begin{tabular}{|l|l|}
\hline Sector scope & Project activities \\
\hline Energy industry & Solar Water Heater Wind Power \\
\hline Energy demand & $\begin{array}{l}\text { CFL, Street Lighting, water } \\
\text { pumping }\end{array}$ \\
\hline
\end{tabular}




\begin{tabular}{|l|l|}
\hline & Building energy efficiency \\
\hline Construction & Recyclinng of building material \\
\hline Transport & $\begin{array}{l}\text { Bus Rapid Transit, Retrofit, } \\
\text { electric vehicle }\end{array}$ \\
\hline $\begin{array}{l}\text { Waste handling and } \\
\text { disposal }\end{array}$ & $\begin{array}{l}\text { Landfill Gas Management } \\
\text { Municipal waste management } \\
\text { including recycling and waste } \\
\text { water treatment }\end{array}$ \\
\hline $\begin{array}{l}\text { Aforestation and } \\
\text { deforestation }\end{array}$ & $\begin{array}{l}\text { Creatiion of green areas in and } \\
\text { around the city }\end{array}$ \\
\hline Agriculture & Manure management system \\
\hline
\end{tabular}

\section{Conclusions}

The green city project will definitely lead to the development of Ilam Municipality as a whole. Even the concept of the green city strategic vision can be replicated to the other parts of Nepal. Especially in a metropolitan city like Kathmandu, where the population growth rate is one of the highest in the world, this concept is very much in need. Ilam Municipality can be role model for these cities. As far as the development is concerned, the achievement received by Ilam so far is recommendable. The success of the plastic ban campaign is an example. Through the plastic ban campaign, the municipal solid waste has been reduced to a substantial level.However, there are various aspects that need to be resolved for the fulfilment of the green city strategic vision. The detailed explaination of those various aspects is given below.

\section{Supply of clean driking water}

There should be adequate supply of clean drinking water. But it should also not be ignored that most parts of Ilam municipality area lie at the top of the hill, the river is at the bottom. So, giving due respect to this topographical difficulty, there should be designing of the drinking water supply system. 


\section{Dissemination of information}

Proper dissemination of information of green city is also needed for the fulfilment of the green city strategic vision. Although stakeholders like NCDC are making major efforts in the dissemination of information about green city and its various aspects, these efforts seem to be inadequate.

\section{Forest conservation}

In the area of forest conservation, the forest has been preserved to a substantial extent. But since more than half of the households surveyed use firewood for cooking purpose, other alternatives for the cooking source should be used and marketed.

\section{Solid waste management}

In the aspect of solid waste management, there should be major initiatives from the municipality. And there is much scope in the solid waste management sector, especially in producing compost manure out of the organic waste. As Sudhakar Yedla has pointed out, "In the developing Asian cities, the conditions of high organic content in waste, the prevalence of poverty, the dominant presence of informal sector, scope of organic farming (as they are mostly agriculture-based economies) and cities that have difficulty in introducing efficiency and financing civil services favor the community-based decentralized composting approach to manage municipal solid waste (24). The current landfill site is also very near to the human settlement area. The households living nearby the landfill area complain about bad odour coming out during the monsoon season.

\section{Job creation}

The success of the green city construction lies in its ability to create job and attract the local youth. Currently, Nepal is facing a massive drainage of youth manpower. There are various ways to create jobs such as the construction of green hotels, resorts etc. If the youths are not attracted, then it may be a failure as 
well. When the Chinese village of Huanbaiyu was constructed as a green city model in 2005 , there were expectations from the villagers that jobs would be created. But it was realised that proper investment was not done in that domain. (25)

Overall, it can be said that Ilam Municipality could be a landmark example on how a green city should be, but to reach this status, Ilam Municipality has a long way to go.

\section{Bibliography}

1. [Online] http://global.britannica.com/

EBchecked/topic/287086/Industrial-Revolution.

2. Carbon Capture by Fossil Fuel Plants: An economic Analysis. Islegan, Reichelstein. 1, s.l. : Management Science, Januuary, 2011, Vol. 57.

3. A research Project conducted by The Economist, sponsored by Siemens. The Green city Index. 2012.

4. UN Population Division,2010 stated in Cities: Investing in energy and Resource Efficiency. s.1. : United Nation Environment Programme, 2011.

5. al., Xiao Geng et. The Urban Sustainability Index: A New Tool for Measuring China's cities. s.l. : McKinsey Global Institute, December, 2011.

6. Zhang, Qingfeng and Robert Crooks. Toward an environmentally sustainable future: Country environmental analysis of the People's Republic of China . Mandaluyong City, Phillipines : Asian Development Bank, 2012.

7. et, al Sankhe. India's Urban Awakening: Building Inclusive cities, sustaining economic growth. s.l. : McKinsey Global Institute, April 2010. 
8. Edited By Ancha Srinivasan, Frank Hiroshiling, Hideyuki Nori. Climate Smart Development in Asia: Transition to a Low carbon and climate resilient economies. 2012.

9. Cities: Investing in energy and resource efficiency. s.1. : United Nation Environment Programme, 2011.

10. Adhikari, Ambika Prasad. Towards Developing indicators of environmental sustainability of Kathmandu, Nepal. October, 2008.

11. Adhikari, Ambika Prasad. Towards Developing indicators of environmental sustainability of Kathmandu, Nepal. October, 2008.

12. Dahal, Madan Kumar Dahal and Dev Raj. Environmetal and sustainable development: Issues in Nepalese Perspective. Kathmandu : NEFAS, 1993 (Reprint in 1999).

13. Aranud Brohe, Nick Eyre and Nicholas Howarth. Carbon Market: An international business guide. 2009.

14. Cities: Investing in energy and resource efficiency. s.1. : United Nation Environment Programme, 2011.

15. Dahal, Madan Kumar Dahal and Dev Raj. Environmetal and sustainable development: Issues in Nepalese Perspective. Kathmandu : NEFAS, 1993 (Reprint in 1999).

16. Final Report. Strategic Plan and Action Plan for Solid Waste Management of 15 Municipalities in Nepal. s.1. : SWMTSC, March 2012.

17. Final Report. Strategic Plan and Action Plan for Solid Waste Management of 15 Municipalities in Nepal. s.1. : SWMTSC, March 2012.

18. Strategic Plan for Green city Initiative. s.1. : Ilam Municipality, 2012. 
19. Final Report. Strategic Plan and Action Plan for Solid Waste Management of 15 Municipalities in Nepal. s.1. : SWMTSC, March 2012.

20. Strategic Plan for Green city Initiative. s.1. : Ilam Municipality, 2012.

21. Strategic Plan for Green city Initiative. s.1. : Ilam Municipality, 2012.

22. Cities: Investing in energy and resource efficiency. s.1. : United Nation Environment Programme, 2011.

23. Urban Development Model for the Low-Carbon Green City:The Case of Gangneung. Kwi-Gon Kim, Ph.D. (UCL, England). 2012.

24. Replication of urban innovation prioritization of strategies for the replication of Dhaka's community based decentralized composting model. Yedla, Sudhakar. 1, s.1. : Waste Management and Research, January, 2012, Vol. 30.

25. Schafer, Sarah. Newsweek Report. May10, 2007.

Mr. Poudel (pratikpoudyal@hotmail.com) is pursuing Masters in Technological Economics and Management at School of Economics and Management, Tongji University, Shanghai, PRC. Ms. Shao Ying Hong (shaoyingh@tongji.edu.cn) is Associate Professor at School of Economics and Management in the same University. 